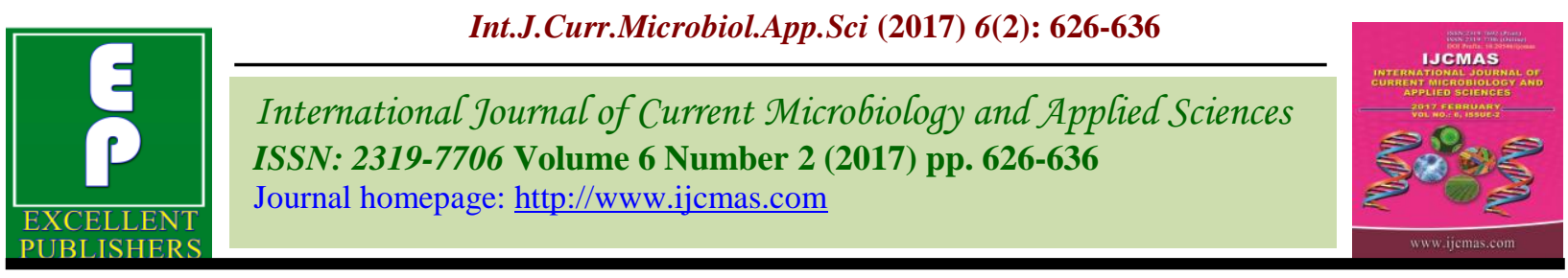

Original Research Article

http://dx.doi.org/10.20546/ijcmas.2017.602.071

\title{
Quality Analysis of Bee Honeys
}

\author{
V. Krishnasree* and P. Mary Ukkuru \\ Department of Home Science, Kerala Agricultural University, College of Agriculture, \\ Vellayani, Trivandrum-695 522, Kerala, India \\ *Corresponding author
}

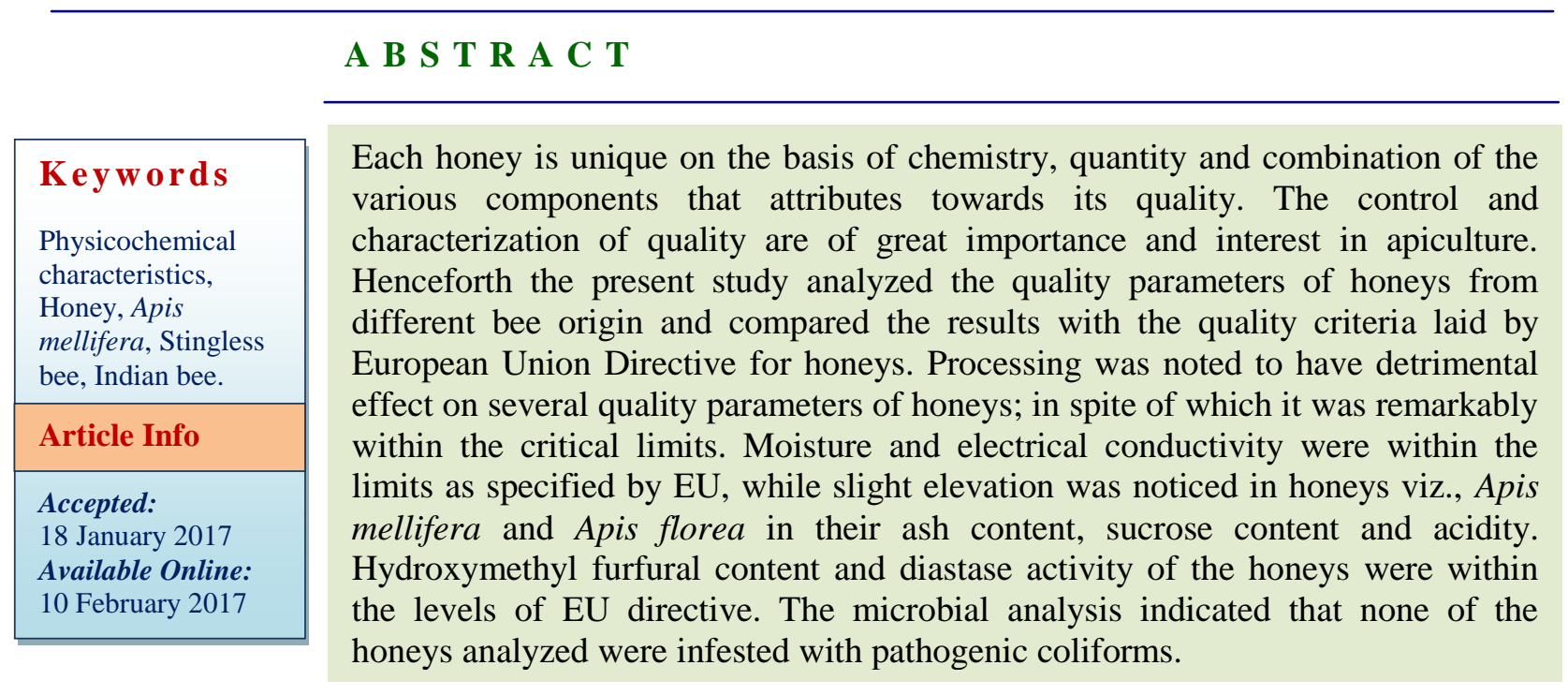

\section{Introduction}

In India, honey is used as nutritional supplement, in therapeutic purposes and also in cosmetic products. Many of these substances give its specific aroma, flavor and some of its biological activity. But these substances are unstable over time and thermolabile. Hence processing methods and period of storage have an impact on the ultimate quality of honey which needs to be analyzed to know the efficacy of raw honey even after processing. Honey has a high commercial significance, although knowledge of the product quality is not adequate. Hence it has become an indispensable part of honey researches to study the quality of honey with specific to the physicochemical characters.

When the food scandals rule the market consumers slowly got linked with the quality of honey based on origin. For example, honey produced in non-EU countries was discovered within European Community, adulterated with high fructose corn syrup; there were identified other incidents where excessive antibiotics residues have been found in honey derived from third-world countries (Ochi, 2005). Therefore the quality standards stress the importance of the quality of honey that is 
linked to the origin and which is used to promote sales through specific labeling.

Unifloral or multifloral, organic protected designation of origin are a few of designations used for honey, that provide scientists with a challenge in terms of confirming labeling that will satisfy consumers, honey industry and control bodies. Moreover, scientists are requested to provide methods and markers that establish the compliance of honey with regulatory requirements. Consequently, finding suitable chemical markers indicating the specific quality of honey linked to origin has been the focus of many studies in the last decade. This includes the studies dealing with the volatile compounds (Cuevas-Glory et al., 2007), phenolic content (Pyrzynska et al., 2009), physico chemical parameters (Gobessa et al., 2012), in honey of different floral and geographic origins.

The latest and the most comprehensive one is the study pertaining to the honey of different bee origin that provides the state-of-the-art results attempting to define typical honey compounds most closely associated with bees from which they are obtained. In this context, the present study aims at a systematic approach to understand the quality aspects of different bee honeys.

\section{Materials and Methods}

\section{Sample collection}

A total of five multifloral honey samples (in quadruples each) of, the Indian hive bee, Apis cerana indica F. (Apidae) (Ac), the European or Italian bee, Apis mellifera L. (Apidae) (Am), the rock bee, Apis dorsata F. (Apidae) (Ad), the little bee, Apis florea F. (Apidae) (Af) and Trigona irridipennis S. (Stingless bee) (Ti) were collected from the local beekeepers of different areas of southern zone of Kerala in raw as well as processed form. The processed form of Apis florea bee honey was not available due to the paucity of inventory. The samples collected in January - February of 2015 were stored in half liter pet containers duly labeled with name codes and date of collection. All chemicals used in this study were of analytical grade.

\section{Determination of physicochemical characteristics}

The major physicochemical characteristics viz., moisture, electrical conductivity, ash content, specific gravity, water activity, free acidity, $\mathrm{pH}$ and total soluble solids were determined according to AOAC (2005).

\section{Determination of hydroxymethyl furfural content}

The method used in this study determines the concentration of 5(hydroxyl methyl-) furan 2 - carbaldehyde, defined as the constituents of honey which are capable of combining with barbituric acid and $\mathrm{p}$ - toludine under the conditions of the test. This method describes the determination of hydroxyl methyl furfural in honey and is based on the original method of Winkler (1995).

To aliquot parts of a honey solution, solutions of p- toludine and barbituric acid are added and the resultant colour is measured against a blank in 1-cm cuvettes at $550 \mathrm{~nm}$.

\section{Determination of diastase activity}

A standard solution of starch, capable of developing with iodine a colour in a defined range of intensity, is acted upon by the enzyme in the honey under standard conditions. The diminution in the blue colour is measured at intervals. A plot of absorbance against time is used to determine the time $t_{x}$ required to reach absorbance 0.235 . The diastase number is calculated as 300 divided by $t_{x}$. 


\section{Determination of sugars}

The major analysis done in this category includes total sugars, reducing sugars and non-reducing sugars according to AOAC.

\section{Microbiological analysis}

The honey samples were assessed for the presence of various microorganisms viz., bacteria, coliforms, actinomycetes, fungi and yeasts. Nutrient Agar (NA), Eosin Methylene Blue (EMB), Ken Knights reagent (KE), Rose Bengal (RB) and Yeast Malt Agar (YMA) medium were used for culturing of bacteria, coliforms, actinomycetes, fungi and yeast respectively. The serial dilution of honeys followed by pour plating was employed to estimate the population of viable microorganisms (Johnson et al., 1973).

\section{Statistical analysis}

A complete randomized design and Pearson's correlation were used to calculate the significant differences and correlations in the treatment means respectively. The mean values of the replicate determinations were reported for microbiological analysis.

\section{Results and Discussion}

The results of the major physicochemical characteristics, sugar composition and microbial contamination of the raw and processed honeys analyzed are as follows.

\section{Physicochemical characteristics of bee honeys}

\section{Moisture}

The raw Trigona iridipennis bee honey had the highest (19.79\%) moisture followed by Apis cerana honey (16.6\%), while raw Apis dorsata honey had lowest (10.03\%) moisture content followed by Apis florea honey (11.7\%) and Apis melifera honey (14.38\%). The moisture content of the processed honeys analyzed viz., Ac, Am, Ad and Ti, the highest moisture percentage was obtained in Trigona iridipennis (Ti) honey of $18.34 \%$ followed by Ad honey with $15.01 \%$ of moisture. In the case of processed honeys the lowest moisture content was for Apis mellifera honey (13.3\%) followed by Apis cerana honey (14.7\%). Significant difference in the moisture content was recorded in raw and processed honeys at $\mathrm{p}<0.025$ and processing found to reduce the moisture content among all the honeys except in processed Apis dorsata honey, this might be due to the unscientific way of processing given to Ad honey. All the honeys had moisture content within the limits of EU (European Union) directive of not $>20 \%$. The moisture content of the analyzed samples was consistent with the previously reported values of some Indian honey for which the values ranged from $17.2 \%$ to $21.6 \%$. Overall, the low moisture content in the investigated honey samples suggests that they are of good quality and storage capability. The maximum moisture content was found to be in raw honey species due to the less amount of processing they obtain.

\section{Electrical Conductivity}

The EC values in the investigated honey samples varied in the range of 0.13$0.56 \mathrm{mS} / \mathrm{cm}$ and were within the recommended range (lower than $0.8 \mathrm{mS} / \mathrm{cm}$ ) as suggested in the EU directive. All the raw honeys varied significantly in their electrical conductivity at $p<0.025$. In a previous study by Ouchemoukh et al., (2007) the EC values of some Algerian honeys were reported to be higher $(0.21-1.61 \mathrm{mS} / \mathrm{cm})$.

The EC value depends on the ash and acid content in honey, the higher the content, the higher the resulting conductivity. This 
parameter was recently included in the international standards, replacing the determination of ash content (Alimentarius, 2001). It could be concluded that, among raw and processed honeys analyzed, Ad honey had the highest electrical conductivity which signifies the higher quantity of ionisable organic and inorganic substances present in it.

\section{Ash content}

Among the raw honeys analyzed Apis florea and Apis dorsata had higher levels of ash content of about $1.07 \%$ and $1.02 \%$ respectively. The Apis cerana honey had the next highest amount of ash content with $0.22 \%$ and on processing it had reduced to $0.06 \%$. Ad honey had lower ash content on processing of $0.09 \%$. The raw Apis mellifera (Am) honey and Trigona (Ti) honey had similar levels of ash content of $0.16 \%$ and no significant difference observed between the raw Ad and Af.

An increase in ash content was found to be accompanied by an increase in the electrical conductivity. The high electrical conductivity generally indicates the presence of minerals in honey (Silva et al., 2009). This was proved to be true in the present study as the raw Ad honey had higher ash content likewise the electrical conductivity was also found to be higher.

\section{Specific gravity}

The Apis mellifera honey in the raw as well as processed form had the maximum specific gravity of 1.40 and 1.38 respectively, followed by Apis dorsata honey with 1.37 of specific gravity in raw variety and 1.36 of specific gravity in processed variety.

The Apis cerana honey had similar specific gravity levels in both raw and processed form of 1.36. The raw Trigona honey had a specific gravity of 1.32 which had reduced to 1.30 on processing. The Apis florea honey had the lowest specific gravity of 1.28 among the raw honeys analyzed. Significant difference observed among all the raw honeys at $\mathrm{p}<$ 0.025 level.

\section{Water activity}

The aw of Apis florea honey was found to be 0.63 followed by Apis cerana honey (0.54) and Trigona honey (0.51). The least water activity was noticed in Apis dorsata (0.47) and Apis mellifera (0.44) honeys. On processing there was an increase in the water activity, it was highly evident in Apis dorsata honey where the aw had increased from 0.47 in the raw Ad to 0.61processed Ad honey. The processed Trigona iridipennis honey also exhibited an increased aw of 0.52. These $a_{w}$ values permit to classify honey as an intermediate moisture food, and thus, they are shelf stable for a reasonable period of time.

\section{Free acidity}

The acidity for the raw honeys was recorded as $0.68 \%$ (Apis florea), $0.31 \%$ (Apis mellifera), 0.2\% (Apis dorsata), 0.16\% (Apis cerana) and $0.15 \%$ (Trigona iridipennis). All the raw honeys analyzed exhibited an increased rate of change in the acidity after processing.

Acidity is influenced by chemical properties of the organic and inorganic acids, e.g. the tridimensional molecular structure and the ionization rate in the honey samples and also by the amino acids content provided by the nectar and salivary enzymes of $A$. Mellifera (Crane, 2013). This might be a possible reason for the variation in the acidity levels among the five different bee species analyzed in this study. The differences in the formic acid percentage among the honeys analyzed were also statistically significant at $\mathrm{p}<0.025$ level. 
pH

The $\mathrm{pH}$ for all honeys studied was in range of 3.43 to 4.45 . The highest $\mathrm{pH}$ was viewed in raw Trigona honey (4.45) and the lowest was in processed Apis dorsata honey (3.43). Out of the five raw honeys examined three of them had $\mathrm{pH}$ level < 4 viz., Apis mellifera (3.83), Apis cerana (3.55) and Apis dorsata (3.49) and the rest had $\mathrm{pH}>4$ namely Apis florea honey followed $\mathrm{Ti}$ honey with a $\mathrm{pH}$ of 4.35. The acidic $\mathrm{pH}$ of honey is desirable since acidification has been shown to promote healing by causing oxygen release from hemoglobin. The $\mathrm{pH}$ of honey is low enough to prevent the growth of many species of bacteria. This could be a contributing factor for the extended shelf life of the honeys under the investigation with negligible microbial proliferation.

\section{Total soluble solids}

The total soluble solids of the honeys analyzed had ranged from 75.5 to $79^{\circ}$ Brix. Among the raw honeys studied the highest TSS content was observed in Apis dorsata honey of $79^{\circ}$ Brix followed by Apis florea honey with $77.5^{\circ}$ Brix. In the case of Apis mellifera and Trigona honey the total soluble solids was found to be equal with $76^{\circ}$ Brix and for Apis cerana honey the TSS was $75.5^{\circ}$ Brix.

There was significant difference in TSS among the raw honeys analyzed except for Apis cerana honey, Apis mellifera honey and Trigona iridipennis honey. The TSS of processed honeys ranged from 79 to $77^{\circ}$ Brix. The TSS of Apis dorsata honey was $79^{\circ}$ Brix and $77^{\circ}$ Brix in Trigona honey. The processed Apis cerana and Apis mellifera honeys had similar levels of total soluble solids of $77.5^{\circ}$ Brix. Most of the total soluble solids for honey are sugars. These account for about $80 \%$ or more of solids by weight. All the honey samples analyzed in this study had soluble sugars lesser than $80 \%$. The findings in this study on soluble sugars are in agreement with their total soluble solids content. As there were lesser soluble sugars in the honeys analyzed their TSS also tends to be lower.

\section{Hydroxymethyl furfural content}

The raw Trigona (3.4mg), Apis florea (10.4mg) and Apis dorsata (7.16mg) honeys had lower levels of hydroxymethyl furfural content, while higher levels were detected in Apis cerana (30.01mg) and Apis mellifera (19.64mg). The hydroxymethylfurfural content of processed honeys confirmed that all the honeys had undergone a specific amount of thermal processing. The HMF content for the processed honeys ranged from 6.36 to $51.87 \mathrm{mg} / \mathrm{Kg}$ of honey. The highest HMF was noticed in Apis cerana honey of $51.87 \mathrm{mg}$ followed by Apis mellifera honey with $27.23 \mathrm{mg}$. A moderate elevation of HMF was viewed in Apis dorsata honey with $12.09 \mathrm{mg}$. Among the processed honeys the lowest HMF was obtained for Ti honey with $6.36 \mathrm{mg}$. The hydroxymethylfurfural content varied significantly at $1 \%$ and $5 \%$ among all the honeys analyzed and also specifically between the raw and processed varieties of each honey. It is usual for HMF to be below $10 \mathrm{mg} / \mathrm{kg}$ in fresh extracted honey. In the present study out of the five raw honeys analyzed two of them (Ac and Am) had higher levels of HMF. Levels higher than this may indicate excessive heating during the extraction process.

Even though Apis cerana and mellifera bee honeys had higher levels of HMF than the usual natural honeys they were within the limits prescribed by European Union (1974), Codex (1993) and QSAE (2005). The international food standards requires that the hydroxyl methyl furfural content of honey 
after processing and/or blending shall not be more than $80 \mathrm{mg} / \mathrm{kg}$. This was followed by all the four processed honeys taken for the study.

\section{Diastase activity}

The diastase activity of raw honeys ranged from 36.7 to $57.5 \mathrm{DN}$. The lowest $\mathrm{DN}$ was observed in Apis cerana honey (36.7) DN followed by Apis dorsata honey (48.19) DN. All the other honeys had DN value > 50 among them the highest diastase activity was viewed in Apis florea honey with 57.5 DN, Trigona honey with $55.45 \mathrm{DN}$ and Apis mellifera honey with $52.7 \mathrm{DN}$. On the other hand the diastase activity of the processed honeys ranged from 27.32 DN to 54.26 DN. Similar to the raw Ac honey the lowest diastase activity was obtained by Apis cerana honey among the processed honeys with 27.32 DN. The diastase activity decreased significantly $(1 \%, 5 \%)$ in all the honeys on processing.

It is to be noted that the use of enzyme activities as indicators of honey freshness is often criticized as the enzyme activities in honey depend on the intensity of the nectar flow and the amount of nectar processing by the honey bees (White, 1994). Therefore honey from very rich nectar sources e.g. often show high natural enzyme activities which could be correlated with the results obtained for the Ti honey as it is a multiforaging bee with access to multifloral nectar could also leads to its high diastase activity (55.45)DN.

\section{Correlation of physicochemical characteristics}

The individual differences for each honey might be due to the presence or absence of one physico chemical parameter that can affect the presence or absence of the other which eventually have an impact on the quality of honey. In fact there can be positive as well as negative association between the parameters that determine the quality of honey to be better or worse. Hence a correlation analysis was carried out to know the influence of individual parameters on the overall quality of honey. It was readily depicted in the correlation matrix that positive correlations exist between the $\mathrm{pH}$ and moisture, $\mathrm{pH}$ and acidity, acidity and ash. A very significant correlation was noticed in $\mathrm{pH}$ and moisture $\left(0.577^{* *}\right)$ and acidity and ash $(0.829 * *)$ while a positive correlation exist between $\mathrm{pH}$ and acidity $\left(0.389^{\ddagger}\right)$ significant at $10 \%$ level. Significant difference $(>0.44)$ was noted in specific gravity and electrical conductivity of $0.477^{*}$. A strong negative correlation were observed between total soluble solids and moisture $\left(-0.755^{* *}\right)$ and diastase and hydroxymethyl furfural ($\left.0.749^{* *}\right)$ significant at $1 \%$ level.

Thus it could be concluded that as the $\mathrm{pH}$ of honey increases the diastase activity will also be higher. The hydroxymethyl furfural content and diastase are the two physico chemical parameters that are affected by thermal processing of raw honeys. On thermal processing the diastase content in the honey tends to decrease and the HMF content tends to increase and hence they are negatively correlated.

\section{Sugar profile of bee honeys}

The reducing sugar of raw honeys in the present study ranges from $33.03 \%$ to $67.6 \%$, the highest was acquired by Apis cerana honey $(67.6 \%)$ followed by Trigona honey with $63.8 \%$ and Apis dorsata honey with $62.1 \%$ by mass. The Apis florea honey differed significantly from other raw honeys with least reducing sugars (33.03\%). An average amount of reducing sugars was present in Apis mellifera honey of $59.5 \%$ by mass. Processing had decreased the reducing sugars in the honeys analyzed. Dimins et al., 
(2006) determined the reducing sugars and reported the values in the range of 73.7 to 82.8 per cent which is much higher than the values reported in the present study.

Among the raw honeys highest total sugars was recorded in Apis mellifera honey with $72.14 \%$ by mass followed by Apis cerana and Trigona honey having $71.66 \%$ and $71.61 \%$ by mass of total sugars. The lowest sugars were obtained by Apis florea honey of $54.98 \%$ followed by Apis dorsata honey with $68.75 \%$ by mass and significant difference was noted between these honeys at $\mathrm{p}<0.025$. The obtained result is similar to that reported for Indian and Bangladesh honey samples having relatively higher total sugar contents (62.88$78.32 \%$ and 42.80 to $60.67 \%$ ).

The higher sucrose content was in raw Trigona (19.73\%) and Apis florea (16.08\%) honeys. The lowest sucrose content was noticed in Apis cerana honey (3.80\%) followed by Apis dorsata honey (5.31\%), while the raw Apis mellifera (11.89\%) had moderate levels of sucrose. Significant difference noticed among raw Am, Af, Ti and processed Am and Ti honeys respectively.

The legal limit for sucrose should be less than $5 \%$ on mass basis as stated in the Codex Alimentarius Commission (2001). Honey that adulterated with high fructose syrup is usually high in sucrose level. However the higher levels of sucrose in certain honeys analyzed in the present study can also be due to the lack of conversion of sucrose by the bees.

\section{Microbial contamination of bee honeys}

Apart from the above discussed physicochemical parameters the occurrence of microbial contaminants if any, in the collected honeys were recorded under the study with special reference to detect the presence of bacteria, fecal coliforms, actinomycetes, moulds and yeasts. The raw honeys Apis cerana and Trigona did not show any signs of microbial growth whereas honeys viz., Apis mellifera, Apis dorsata and Apis florea had the presence of microbial strains. Yeast colonies were detected in raw Apis mellifera and Apis florea honeys at a rate of $1 \times 10^{-2}$ $\mathrm{cfu} / \mathrm{g}$. The raw Apis dorsata honey was noticed to have $2 \times 10^{-5} \mathrm{cfu} / \mathrm{g}$ of bacterial strains. Among the processed honeys apart from Trigona honey all the other honeys had fungal and yeast infestations although negligible. Yeast colonies were detected in the processed Apis cerana, Apis mellifera and Apis dorsata honeys at a rate of $2 \times 10^{-2} \mathrm{cfu} / \mathrm{g}$ simultaneously, processed Apis mellifera and Apis dorsata honeys had an occurrence of fungal colonies at a rate of $1 \times 10^{-3} \mathrm{cfu} / \mathrm{g}$.

Table.1 Moisture, EC, ash and specific gravity of bee honeys

\begin{tabular}{|c|c|c|c|c|c|c|c|c|}
\hline \multicolumn{2}{|c|}{ Specific gravity (g) } & \multicolumn{2}{|c|}{ Ash content $(\%)$} & \multicolumn{2}{|c|}{$\begin{array}{c}\text { Electrical } \\
\text { conductivity } \\
(\mathrm{mS} / \mathrm{cm})\end{array}$} & \multicolumn{2}{|c|}{ Moisture content (\%) } & \multirow[t]{2}{*}{ Species } \\
\hline $\begin{array}{c}\text { Processe } \\
\mathrm{d}\end{array}$ & Raw & Processed & Raw & Processed & Raw & Processed & Raw & \\
\hline 1.36 & 1.36 & 0.06 & 0.22 & 0.24 & 0.41 & 14.7 & 16.6 & $\mathrm{Ac}$ \\
\hline 1.38 & 1.40 & 0.14 & 0.16 & 0.13 & 0.31 & 13.3 & 14.38 & $\mathrm{Am}$ \\
\hline 1.36 & 1.37 & 0.09 & 1.02 & 0.34 & 0.56 & 15.01 & 10.03 & Ad \\
\hline-- & 1.28 & - & 1.07 & - & 0.26 & - & 11.7 & Af \\
\hline 1.30 & 1.32 & 0.16 & 0.16 & 0.33 & 0.35 & 18.34 & 19.79 & $\mathrm{Ti}$ \\
\hline 0.030 & 0.003 & 0.003 & 0.061 & 0.030 & 0.030 & 0.572 & 0.770 & $\mathrm{CD}$ \\
\hline
\end{tabular}


Table.2 Water activity, free acidity, pH and TSS of bee honeys

\begin{tabular}{|c|c|c|c|c|c|c|c|c|}
\hline \multicolumn{2}{|c|}{ TSS ( } & \multicolumn{2}{c|}{$\mathrm{pH}$} & \multicolumn{2}{c|}{$\begin{array}{c}\text { Free acidity (formic } \\
\text { acid \%) }\end{array}$} & \multicolumn{2}{c|}{ Water activity $\left(\mathrm{a}_{\mathrm{w}}\right)$} & \multirow{2}{*}{ Species } \\
\cline { 1 - 7 } Processed & Raw & Processed & Raw & Processed & Raw & Processed & Raw & \\
\hline 77.5 & 75.5 & 3.56 & 3.55 & 0.19 & 0.16 & 0.56 & 0.54 & $\mathrm{Ac}$ \\
\hline 77.5 & 76 & 3.73 & 3.83 & 0.32 & 0.31 & 0.53 & 0.44 & $\mathrm{Am}$ \\
\hline 79 & 79 & 3.43 & 3.49 & 0.22 & 0.2 & 0.61 & 0.47 & $\mathrm{Ad}$ \\
\hline- & 77.5 & - & 4.35 & - & 0.68 & - & 0.63 & Af \\
\hline 77 & 76 & 3.77 & 4.45 & 0.16 & 0.15 & 0.52 & 0.51 & Ti \\
\hline 0.003 & 0.662 & 0.030 & 0.090 & 0.003 & 0.210 & 0.023 & 0.027 & CD \\
\hline
\end{tabular}

Table.3 Correlation matrix of physicochemical characteristics of bee honeys

\begin{tabular}{|c|c|c|c|c|c|c|c|c|c|}
\hline $\begin{array}{l}\text { Diastase } \\
\text { activity }\end{array}$ & Acidity & HMF & Moisture & $\begin{array}{c}\text { Total } \\
\text { ash }\end{array}$ & TSS & $\mathrm{pH}$ & $\begin{array}{c}\text { Electrical } \\
\text { conductivity }\end{array}$ & $\begin{array}{l}\text { Specific } \\
\text { gravity }\end{array}$ & \\
\hline & & & & & & & & & $\begin{array}{c}\text { Specific } \\
\text { gravity }\end{array}$ \\
\hline & & & & & & & & $0.47 *$ & $\begin{array}{c}\text { Electrical } \\
\text { conductivity }\end{array}$ \\
\hline & & & & & & & $-0.89 *$ & $-0.68 * *$ & $\mathrm{pH}$ \\
\hline & & & & & & & $0.53 *$ & & TSS \\
\hline & & & & & & $0.55^{*}$ & $-0.55^{*}$ & $-0.79 * *$ & Total ash \\
\hline & & & & & $\begin{array}{c}- \\
0.75^{* *}\end{array}$ & $\begin{array}{c}0.57^{*} \\
*\end{array}$ & $-0.48 *$ & & Moisture \\
\hline & & & & & $-0.52^{*}$ & & & 0.42 & HMF \\
\hline & & & -0.37 & $0.82 * *$ & & 0.38 & $-0.46^{*}$ & $-0.50^{*}$ & Acidity \\
\hline & $0.48^{*}$ & $-0.74 * *$ & & $0.57 * *$ & & $\begin{array}{c}0.68^{*} \\
*\end{array}$ & $-0.55^{*}$ & $-0.47 *$ & $\begin{array}{l}\text { Diastase } \\
\text { activity }\end{array}$ \\
\hline
\end{tabular}

Table.4 Sugar composition of bee honeys

\begin{tabular}{|c|c|c|c|c|c|c|}
\hline \multicolumn{2}{|c|}{ Non-reducing sugars (\%) } & \multicolumn{2}{c|}{ Total sugars (\%) } & \multicolumn{2}{c|}{ Reducing sugars (\%) } & \multirow{2}{*}{ Species } \\
\hline Processed & Raw & Processed & Raw & Processed & Raw & \\
\hline $1.09(1.26)$ & $3.80(2.07)^{\ddagger}$ & 61.45 & 71.66 & 60.3 & 67.6 & $\mathrm{Ac}$ \\
\hline $8.53(2.99)$ & $11.89(3.50)$ & 63.76 & 72.14 & 54.34 & 59.5 & $\mathrm{Am}$ \\
\hline $2.3(1.63)$ & $5.31(2.37)$ & 59.35 & 68.75 & 57.16 & 62.1 & $\mathrm{Ad}$ \\
\hline- & $16.08(3.87)$ & - & 54.98 & - & 33.03 & $\mathrm{Af}$ \\
\hline $18.39(2.66)$ & $19.73(2.78)$ & 70.06 & 71.61 & 62.9 & 63.8 & $\mathrm{Ti}$ \\
\hline 0.431 & 1.084 & 0.770 & 1.566 & 2.528 & 4.277 & $\mathrm{CD}$ \\
\hline
\end{tabular}


Fig.1 HMF content of bee honeys

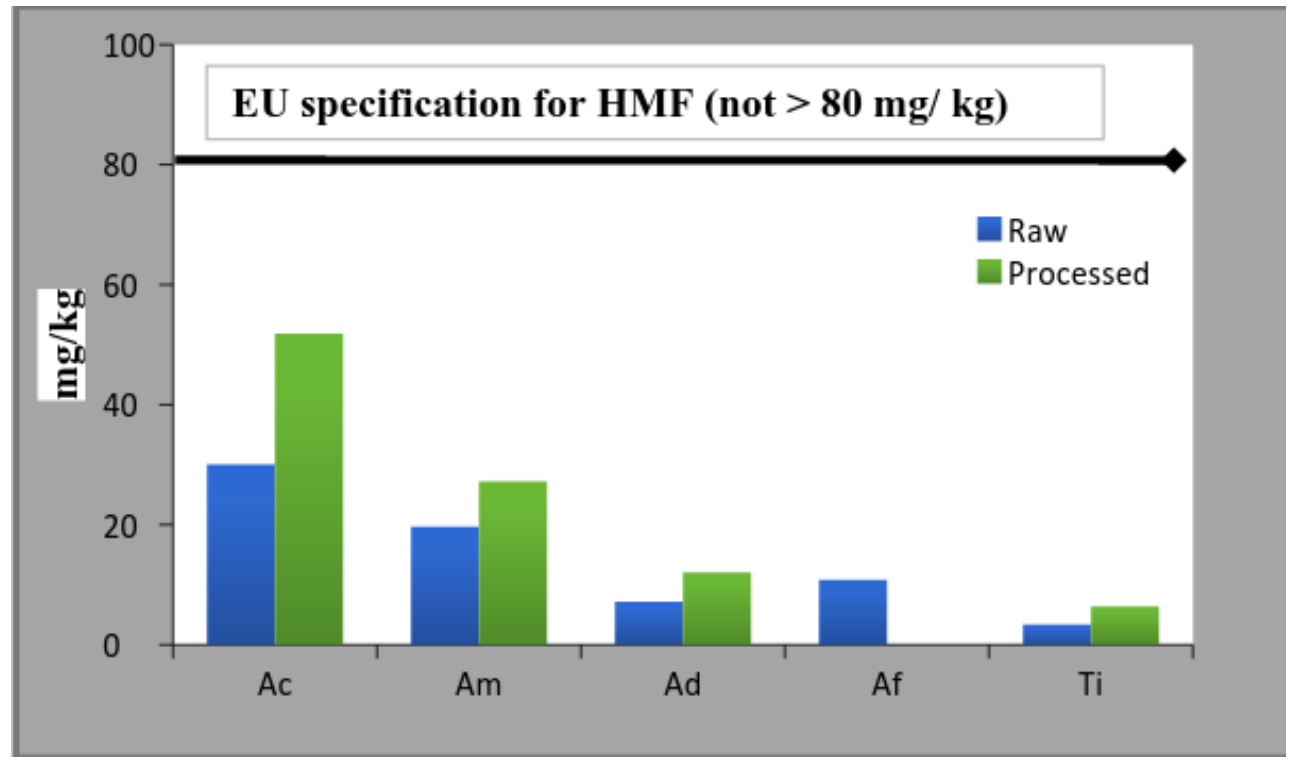

Fig.2 Diastase activity of bee honeys

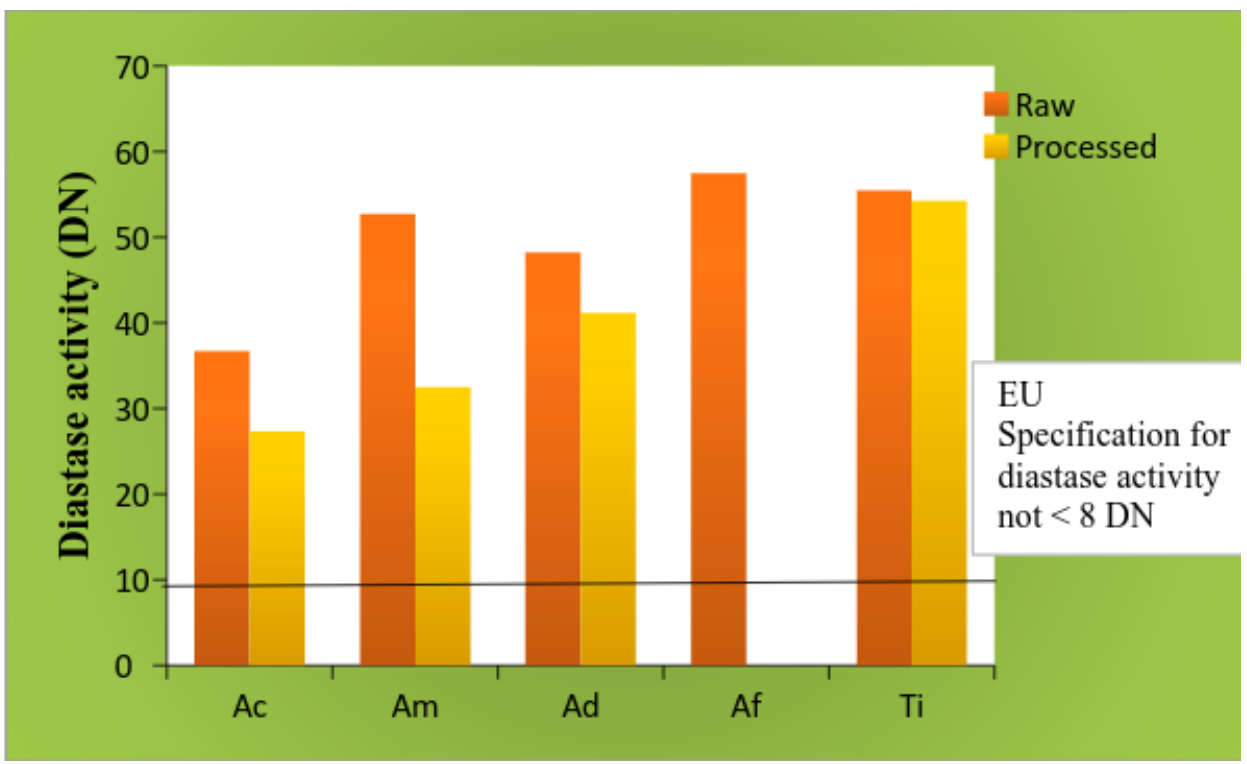

Evidence based data clearly indicated the raw as well as processed Trigona honeys were free of microbial infestation throughout the study. The microbial analysis revealed the presence of fungal and yeast colonies in negligible levels, while pathogenic organisms were absent in all the honeys analyzed. Levels of quantification for commercial quality parameters with respect to the presence of aerobic bacteria, moulds and yeast in the analyzed processed honey samples were lower than those reported by other authors. Iurlina and Fritz (2005) found higher levels of contamination for both bacteria (average $244 \mathrm{cfu} / \mathrm{g}$ ) and mould and yeast (34 cfu/g) counts. The absence of fecal coliforms also 
enforced the sanitary quality and safety of the honeys analyzed in the current investigation. In contrast, Finola et al., (2007) reported that $70 \%$ of 23 honey samples analyzed in their study were contaminated with coliforms and clostridia.

In conclusion, all the honeys analyzed in the present study were established to have exportable quality with all the physicochemical characteristics in the acceptable range and complies with the requirements of the current European Union Directives. However it should be noted that raw honeys have better characteristics when compared to their thermally processed counterparts, as high rate of influence were observed on the characteristics like hydroxymethylfurfural content, diastase activity, moisture content, total ash and electrical conductivity. Hence it could be concluded that there is a need for reformulating the traditional practices of harvesting and storage of honey with novel scientific techniques among the local apiculturists so as to improve the therapeutic potency and economic value of the honey in the international markets.

\section{Acknowledgement}

The authors wish to thank Kerala Agricultural University for providing an opportunity to carry out this research project.

\section{References}

Alimentarius, C. 2001. Revised codex standard for honey, Codex stan. 12, 19 82.

AOAC. 2005. Official methods of Analysis of Association of Analytical chemist (AOAC) International, 18th edition by Dr. Willium Horowitz Vol 1 and 2, 920.58, 920.56, 969.12, 976.11.
Bogdanov, S., Martin, P., and Lullmann, C. 2002. Harmonised methods of the international honey commission, FAM, Liebefeld: Swiss. Bee. Res. Cent., p. 110.

Codex Alimentarious. 1993. Standard for honey. Ref. Nr. CL 1993/14-SH. Food and Agriculture Organization of the United Nations and World Health Organization, Rome, p. 21.

Codex Alimentarius Commission. 2001. Adopting the draft revised standard for honey. Alinorm01/25, Appendix II: 22 24. Cotte J.F.,Casabianca H, 24th Session, July 2001, p. 21.

Crane, E. 1979. Honey: A comprehensive survey. International Bee Research Association (IBRA), Heinemann, London.

Crane, E. 2013. The archaeology of beekeeping, Gerald Duckworth \& Co. Ltd. London, p. 4.

Cuevas-Glory, L.F., Pino, J.A., Santiago, L.S., and Sauri-Duch, E. 2007. A review of volatile analytical chemistry for determining the botanical origin, Food Chem., 103 1032-1043.

Dimins, F., Kuka, P., Kuka, M., and Caste, I. 2006. The criteria of honey quality and its changes during storage and thermal treatment, Latvijas Lauksaiminie-LibasUniversitate- Raksti., (16) 73-78.

European Union. 1974. Honey Directive. On the harmonization of the laws of the member states relating to honey.74/409/EEC, Off. J. Eur. Commun., NOL 221/14.

Finola, M.S., Lasagno, M.C., and Marioli, J.M. 2007. Microbiological and chemical characterization of honeys from central Argentina, Food Chem., 100(4): 1649-1653.

Gobessa, S., Seifu, E., and Bezabih, A. 2012. Physicochemical properties of honey produced in Homesha district of 
Ethiopia, J. Apicultural Sci., 56(1) 3340.

Islam, M., Moniruzzaman, M., Mottalib, M., Sulaiman, S.A., Gan, S.H., and Khalil, M. 2012. Physicochemical and antioxidant properties of Bangladeshi honeys stored for more than one year, BMC Complement Altern. Med., 12(1): 177.

Iurlina, M.O., and Fritz, R. 2005. Characterization of microorganisms in Argentinean honeys from different sources, Int. J. Food Microbiol., (105): 297-304.

Johnson, M.L., and Curl, T. 1973. Standard methods of biochemical analysis, Kalyani publishers, New Delhi, pp. 62 65 .

Krauze, R., and Zalewiski. 1973. Classification of honeys by principal component analysis on the basis of chemical and physical parameters, Z . Lebensm. Unters. Forsch., 192. 19 - 23.

Leveen, H.H., Falk, G., and Bore, K.B. 1973. Chemical acidification of wounds; an adjuvant to healing and the unfavourable action of alkalinity by ammonia, Ann. Surg., (187): 745-753.

Ochi, T. 2005. Former Japanese beekeeper speaks out about antibiotics in Chinese honey, Am. Bee J., 145(12): 973 - 938.

Ouchemoukh, S., Louaileche, H., and Schweitzer, P. 2007. Physicochemical characteristics and pollen spectrum of some Algerian honeys, Food Control. 8(1) $52-58$.

Pyrzynska, K., and Biesaga, M. 2009. Analysis of phenolic acids and flavonoids in honey, Trends in Anal. Chem., 28(7), 893 -902.

QSAE. 2005. Quality Standard Authority of Ethiopia. Ethiopian standard specifications for bees wax (ES 1203:2005), honey (ES 1202:2005) and bee hives (ES 1204:2005.

Saxena, S., Gautam, S., and Sharma, A. 2010. Physical, biochemical and antioxidant properties of some Indian honeys, Food Chem., 118(2) 391-397.

Silva, L.R., Videira, R., Monteiro, A.P., Valentao, P., and Andrade, P.B. 2009. Honey from Luso region (Portugal): Physicochemical characteristics and mineral contents, Microchemical. J., (93) 73-77.

Sua, Y., Browna, H.M., Huanga, X., Zhoua, X., Amonettea, J.E., and Zhang, Z.C. 2009. Single-Step Conversion of Cellulose to 5-hydroxymethylfurfural (HMF), a Versatile Platform Chemical, Appl. Catal. A., 361(12) 117-122.

White, J.W. 1994. The role of HMF and diastase assays in honey quality evaluation, Bee World, (75): $104-117$.

Winkler, O. 1995. Detection and determination of hydroxymethyl furfural in honey, Z. Lebensm. Unters For., 102: $161-167$.

\section{How to cite this article:}

Krishnasree, V., and Mary Ukkuru, P. 2017. Quality Analysis of Bee Honeys. Int.J.Curr.Microbiol.App.Sci. 6(2): 626-636. doi: http://dx.doi.org/10.20546/ijcmas.2017.602.071 